\title{
PENGEMBANGAN MODUL PEMBUATAN KANTONG PADA MATA KULIAH TEKNOLOGI BUSANA JURUSAN IKK FPP UNP
}

\author{
Fadilla Fitri ${ }^{*}$, Adriani ${ }^{2 *}$ \\ Program Studi Pendidikan Kesejahteraan Keluarga Jurusan Ilmu Kesejahteraan Keluarga \\ Fakultas Pariwisata dan Perhotelan \\ Universitas Negeri Padang \\ Jl. Prof. Dr. Hamta, Air Tawar Padang, Kel. Air Tawar Barat, Kec. Padang Utara, Kota Padang, Kode Pos 25171 \\ Sumatera Barat. Indonesia \\ Email:fadilla24march@gmail.com
}

\begin{abstract}
Abstrak
Penelitian ini bertujuan menghasilkan media berbentuk modul pembelajaran yang valid dan praktis yang dapat membantu mahasiswa dalam pembelajaran Teknologi Busana khususnya Teknik Pembuatan Kantong. Penelitian ini merupakan penelitian dan pengembangan atau research and development yaitu motode penelitian yang digunakan untuk menghasilkan produk tertentu dan menguji kelayakan produk terserbut. Prosedur pengembangan menggunakan model 4D. Karena keterbatasan peneliti maka penelitian ini hanya sampai tahap develop saja. Modul ini diuji validitas nya oleh 2 orang ahli media dan 2 orang ahli materi. Uji praktikalitas dilakukan pada mahasiswa S1 Tata Busana angkatan 2018 dengan jumlah 30 orang. Teknik analisis data menggunakan presentase. Berdasarkan hasil penelitian, uji validitas dilakukan kepada validator memperoleh skor $81,14 \%$ dengan kategori sangat valid. Sedangkan hasil uji praktikalitas yang dilakukan kepada dosen dan mahasiswa diperoleh 88,07\% dengan kategori sangat praktis. Modul ini berada dalam kriteria layak digunakan sebagai media pembelajaran mata kuliah Teknologi Busana.
\end{abstract}

Kata Kunci: modul, media pembelajaran, teknologi, busana.

\begin{abstract}
This research aims to produce valid and practical learning media in the form of learning modules that can help students in learning Fashion Technology, especially in Sewing Pocket Techniques. This research is research and development, the research method used to produce certain products and test the expedience of these products. The development procedure uses a $4 \mathrm{D}$ model. Because of the limitations of the researchers, this study only reached the develop stage. This module is tested for its validity by 2 media's experts and the subject's experts. Practical tests are carried out on 2018 Bachelor of Fashion students with 30 people. Data analysis techniques use percentages. Based on the results of the study, the validity test performed on the validator scored $81.14 \%$ with a very valid category. While the results of practical tests conducted to lecturers and students obtained $88.07 \%$ with very practical categories. This module is in the proper criteria to be used as a learning media for Fashion Technology courses.
\end{abstract}

Keywords: module, learning media, technology, clothing.

\section{PENDAHULUAN}

Fakultas Pariwisata dan Perhotelan merupakan salah satu fakultas yang ada di Universitas Negeri Padang, pada Jurusan Ilmu kesejahteraan Keluarga khususnya pada konsentrasi Tata Busana terdapat dua jenjang prodi yaitu D3 Tata Busana dan S1 Pendidikan Kesejahteraan Keluarga. Terdapat salah satu mata kuliah yang ada di jurusan IKK yaitu Teknologi Busana merupakan keterampilan dasar dalam membuat busana dengan bobot 3 sks, 1 sks teori dan 2 sks praktek yang diikuti oleh mahasiswa semester 1 pada kedua prodi baik D3 maupun S1.

Mata kuliah teknologi busana merupakan salah satu mata kuliah kejuruan yang penting bagi Jurusan Ilmu
Kesejahteraan Keluarga konsentrasi Pendidikan Tata Busana. Mata kuliah ini diajarkan pada mahasiswa pada semester 1. Capaian pembelajaran Teknologi Busana yaitu mahasiswa dapat berfikir kritis, cerdas dan teliti dalam memahami pengetahuan dan keterampilan tentang konsep teknologi busana. Salah satunya tentang Teknik Pembuatan Kantong. Capaian pembelajaran dalam materi ini adalah mampu membuat pembuatan kantong dalam bentuk fragmen dengan pengalaman belajar berupa praktek dalam waktu 6x50 menit, materi pembuatan kantong ini dipelajari pada minggu ke 8 . 


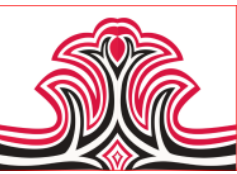

Kantong merupakan salah satu bagian pada pakaian yang dapat menambah keindahan pakaian atau berfungsi sebagai tempat penyimpanan, kantong memiliki berbagai macam variasi sehingga menambah keindahan pada pakaian. Pada proses pembuatan kantong, pemotongan dan menjahit pada pakaian dibutuhkan teknik yang benar dan ketelitian dalam bekerja yang harus dikuasai oleh mahasiswa karena berpengaruh kepada mutu pakaian dan hasil yang didapatkan sesuai dengan pencapaian pembelajaran

Salah satu sumber belajar yang dapat digunakan dalam membantu proses pembelajaran adalah modul. Modul merupakan bahan ajar cetak yang dirancang secara sistematis berdasarkan kurikulum tertentu dan dikemas dalam bentuk satuan pembelajaran terkecil dan memungkinkan dipelajari secara mandiri dalam satuan waktu tertentu (Purwanto, 2007: 9). Sedangkan menurut Vembriarto (1987:20) suatu modul pembelajaran adalah suatu paket pengajaran yang memuat satu unit konsep daripada bahan pelajaran. Pengajaran modul merupakan usaha penyelenggaraan pengajaran individual yang memungkinkan siswa menguasai satu unit bahan pelajaran sebelum dia beralih ke unit berikutnya.

Dari pendapat di atas dapat disimpulkan bahwa melalui media modul mahasiswa dapat melakukan kegiatan belajar mandiri tanpa mengalami banyak kesulitan. Media pembelajaran berupa modul ini sangat penting dalam pembelajaran karena membantu mahasiswa untuk belajar secara mandiri karena dalam satu modul sudah berisi materi pembelajaran, metode, batasan-batasan, dan cara mengevaluasi kemampuan tiap individu yang disajikan secara sistematis dan menarik untuk mencapai tingkatan kompetensi yang diharapkan.

Agar pembelajaran dapat terlaksana sesuai dengan target pencapaiannya, diperlukan pengembangan bahan ajar yang efektif, efisien dan praktis. Tetapi pada mata kuliah Teknologi Busana belum memiliki modul yang praktis dan valid. Validitas adalah keadaan yang menggambarkan suatu instrumen tersebut mampu mengukur apa yang akan diukur, dalam artian validitas menjadi alat untuk memastikan seberapa baik instrumen itu digunakan untuk mengukur konsep yang seharusnya diukur. (Suharsimi 2010:167)

Praktikalitas dapat terlihat apabila memenuhi aspek kemudahan pengguna, waktu yang digunakan, daya tarik produk, mudah diterapkan oleh pendidik ahli ataupun pendidik lain dan memiliki ekivalensi yang sama dengan media atau metode lain sehingga bisa digunakan pengganti atau variasi. (Muhibin 2008:52) Dapat disimpulkan dengan melaksanakan eksperimen dengan menggunakan perangkat pembelajaran yang telah direvisi berdasarkan penilaian oleh validator. Media dikatakan memiliki praktikaitas yang tinggi apabila bersifat praktis dan mudah pengadministrasiannya, dalam arti mudah
Gorga Jurnal Seni Rupa

Volume 08 Nomor 01 Januari-Juni 2019

p-ISSN: 2301-5942 | e-ISSN: 2580-2380

digunakan, mudah pemeriksaannya, serta lengkap dengan petunjuk yang jelas.

Dari kedua pendapat di atas dapat disimpulkan bahwa suatu media yang valid dan praktis dapat menghasilkan bahan ajar yang membantu dalam peningkatan mutu pembelajaran, dapat digunakan oleh pendidik dan peserta didik. Kepraktisan isi materi sesuai dan disusun secara sistematis sehingga materi dan tujuan pembelajaran dapat berjalan dengan baik.

Penulis melakukan wawancara pada tanggal 14 Februari 2018, pada beberapa mahasiswa yang sudah mengikuti mata kuliah Teknologi Busana bahwa media pembelajaran yang digunakan adalah jobsheet. Penggunaan jobsheet sebagai bahan ajar dalam mata kuliah ini belum bisa dikatakan efektif karena hanya berisikan materi pembelajaran secara ringkas dan umum. Jobsheet ini juga digunakan secara mandiri saat melanjutkan tugas dirumah.

Dari wawancara yang dilakukan kepada mahasiswa dapat disimpulkan bahwa dalam mata kuliah Teknologi Busana belum terdapat media modul sebagai penunjang dalam pembelajaran. Jika dilihat dari hal ini maka media pembelajaran yang lebih lengkap dan efektif untuk mengatasi permasalahan ini sangat dibutuhkan oleh mahasiswa.

Seperti yang kita ketahui, praktek menjahit atau membuat fragmen dalam pembelajaran membutuhkan media pembelajaran berisi langkah kerja yang rinci agar hasil praktek menjadi maksimal untuk digunakan oleh mahasiswa semester 1 yang baru memasuki perkuliahan tata busana. Kecepatan, ketepatan dan daya serap mereka dalam memahami materi dan bekerja juga berbeda-beda pada setiap orang.

Waktu yang disediakan untuk mempelajari materi pembuatan kantong hanya $6 \times 50$ menit atau 2x pertemuan. Mahasiswa diharapkan untuk mempraktekkan semua materi teknik pembuatan kantong dengan optimal sementara waktu yang dimiliki kurang mencukupi sehingga perlu dilakukan penambahan waktu diluar jam perkuliahan, sementara untuk bekerja secara mandiri dibutuhkan panduan.

Untuk membantu mahasiswa dalam menyelesaikan permasalahan tersebut dapat digunakan media lain yaitu dengan modul. Modul akan sangat membantu mahasiswa dalam belajar secara mandiri baik itu di kampus ataupun di rumah.

Dari sekian banyak media pembelajaran, penulis memilih modul sebagai media dalam mata kuliah teknologi busana ini karena dilihat dari karakteristik modul tersebut dapat membantu mahasiswa karena berisi materi atau konsep dasar suatu topik, langkah demi langkah dalam menjahit mulai dari persiapan hingga pembuatan akhir. Dan setiap materi maupun langkah kerja dilengkapi dengan gambar untuk membuka wawasan mahasiswa serta memudahkan dalam mempraktekkan teknik-teknik dalam menjahit. 


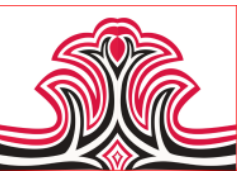

Dengan ini mahasiswa mampu mencocokkan antara apa yang sedang dikerjakan dengan petunjuk yang di lihat didalam modul. Dalam modul juga terdapat rangkuman pada akhir materi, soal latihan untuk menguji kemampuan mahasiswa dalam memahami materi. Semuanya terdapat dalam satu paket modul yang memungkinkan mahasiswa menguasai satu materi pelajaran sebelum beralih ke materi berikutnya. Berdasarkan latar belakang di atas penulis tertarik untuk membuat modul sebagai salah satu media pembelajaran yang dapat meningkatkan ketercapaian hasil belajar mahasiswa mengenai Teknologi Busana dengan penelitian merancang dan mengembangkan media pembelajaran serta mengetahui respon dosen dan mahasiswa dari penelitian ini. Salah satu unit pembelajaran dalam mata kuliah Teknologi Busana yang dikembangkan menjadi modul adalah kompetensi Pembuatan Kantong.

\section{KAJIAN TEORI}

Kantong pada pakaian mempunyai tujuan yang berbeda mulai dari berguna untuk menempatkan sesuatu sampai kepada hiasan. Menurut Goet Poespo (2009:24) "kerah, manset, saku dan ban dapat menjadi penunjang penampilan busana secara keseluruhan". Kantong bermacam-macam bentuk, ukuran dan hiasannya dari berbagai bentuk, ukuran serta hiasan kantong tersebut dapat dikelompokkan menjadi dua kelompok yaitu kantong tempel dan kantong dalam.

Menurut Wildati (2007:193) ada dua jenis kantong yaitu kantong tempel (patch pocket) dan kantong dalam (inside pocket). kantong tempel yaitu seluruh bagian kantong keliatan pada bagian luar pakaian. Kantong dalam yaitu bagian kantong yang tersembunyi pada bagian dalam pakaian, yang terlihat dari bagian luar pakaian hanya bukaan kantongnya. Kantong dalam terbagi menjadi tiga macam yaitu :1) kantong dalam kampuh (in seam pocket) 2) kantong samping (slanted pocket) dan 3) kantong bercelah (slashed pocket).

\section{METODE PENELITIAN}

Berdasarkan tujuan dari penelitian yaitu mengembangkan modul pembuatan kantong Teknologi Busana, maka jenis penelitian yang digunakan adalah penelitian dan pengembangan (Research and Development). Produk yang dikembangkan modul pembuatan kantong pada mata kuliah Teknologi busana, dalam kompetensi membuat pembuatan kantong.

Dalam penelitian ini adalah model pengembangan (research and development) adalah metode penelitian yang digunakan untuk menghasilkan produk tertentu,
Gorga Jurnal Seni Rupa

Volume 08 Nomor 01 Januari-Juni 2019

p-ISSN: 2301-5942 | e-ISSN: 2580-2380

dan menguji keefektifan produk tersebut (Sugiyono 2009:407) model pengembangan ini menggunakan metodae 4-D. model pengembangan ini menurut mempunyai empat tahapan dalam pengembanganya, yaitu tahap 1 (define), tahap II (design), tahap III (develope), dan tahap IV (disseminate) (Thiagarajan, dkk dalam Trianto 2009:189)

Pada tahap pendefinisian (define) berutujuan untuk menetapkan dan mendefinisikan pembelajaran sesuai dengan tujuan penelitian. Tujuan dari tahap ini adalah menentukan dan menetapkan syarat-syarat pembelajaran diawali dengan analisis tujuan dari batasan materi yang dikembangkan perangkatnya. Tahap ini meliputi a) analisis ujung depan, b) analisis siswa, c) analisis tugas d) analisis konsep dan e) perumusan tujuan pembelajaran. Tahap perancangan (design) adalah tahap untuk menyiapkan pembelajaran yang terdiri dari 1) menganalisi materi mata kuliah yang dijadikan isi modul 2) mengumpulkan informasi yang dimaksud supaya modul yang akan dihasilkan tidak menyimpang dari tujuan pembelajaran 3) menyusun kerangka modul pembelajaran (Trianto (2015-233)

Tahap pengembangan (develop) menghasilkan perangkat pembelajaran yang sudah di perbaiki berdasarkan masukan dari pakar media dan materi. Tahap ini meliputi: tahap validasi revisi dan tahap praktikalitas. Tahap validasi pada modul ini dilakukan oleh orang 4 orang validator: 2 orang dosen ahli media dan 2 orang ahli materi. Kemudian revisi dilakukan berdasarkan masukan dari validator. Revisi dilakukan agar menghasilkan modul yang layak digunakan saat praktikalitas. Tahap praktikalitas dilakukan dengan uji coba kelompok kecil melibatkan 6 mahasiswa yang dipilih secara acak, kemudian uji coba kelompok besar yang melibatkan 30 mahasiswa dan uji coba dengan dosen pembimbing mata kuliah teknologi busana.

Jenis data yang diambil adalah data primer. Data diambil dari hasil uji validasi dari validator. Data dari pelaksanaan uji praktikalitas dari mahasiswa dan dosen dengan menggunakan modul teknik pembuatan kantong. Teknik pengumpulan data dengan cara observasi dan angket.

\section{HASIL DAN PEMBAHASAN \\ 1.Hasil}

\section{1).Tahap Pendefenisian (Define)}

Pada tahap pendefinisian, penulis melakukan analisis yang menjadi pedoman untuk proses pembuatan modul pembuatan kantong. Pada tahap analisis siswa, tugas, konsep dan analisis perumusan tujuan 


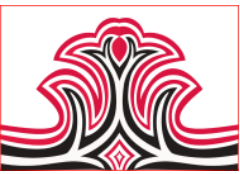

pembelajaran ditemukan masalah yang menjadi latar belakang pembuatan modul, yaitu 1) Belum tersedianya modul untuk materi Pembuatan Kantong pada Mata Kuliah Teknologi Busana yang telah valid dan praktis. 2) Mahasiswa kesulitan dalam menyelesaikan tugas Pembuatan Kantong sehingga harus menyelesaikan tugas-tugas diluar jam pelajaran secara mandiri. 3) Kurangnya pengetahuan mahasiswa tentang teknik Pembuatan Kantong.

\section{2).Tahap Perancangan (Design)}

Tahap perancangan (design) modul Pembuatan Kantong dalam mata kuliah Teknologi Busana Terdiri dari 1) Menganalisis materi mata kuliah yang dijadikan isi modul. Materi yang digunakan adalah materi pembuatan kantong yang berpedoman pada silabus Teknologi Busana pada pertemuan ke 8 dengan total waktu 6x 50 menit. 2) Menyusun kerangka modul pembelajaran atau garis-garis besar modul. 3) Mengembangkan materi yang telah dirancang dalam kerangka modul. 4) Menyusun kerangka/sistematika modul.

\section{3).Tahap Pengembangan (Develop)}

Tahap pengembangan (develop) merupakan tahap untuk menghasilkan perangkat pembelajaran yang sudah diuji validasi dan praktikalitas yang diikuti dengan revisi berdasarkan masukan dari para ahli. Tahap ini meliputi:

\section{(1).Validasi Modul Pembelajaran}

Validasi modul pembelajaran dilakukan oleh ahli media dan ahli materi. Tahap validasi dilakukan untuk menghasilkan modul yang valid dan layak unutuk digunakan sebagai modul pembelajaran.

Tabel 1. Hasil Validitas oleh Ahli Materi

\begin{tabular}{|c|l|c|c|}
\hline No. & Aspek Penilaian & $\begin{array}{c}\text { Hasil Validasi } \\
(\boldsymbol{\%})\end{array}$ & Kategori \\
\hline 1 & Kelayakan Isi & $84,67 \%$ & Sangat Valid \\
\hline 2 & Penyajian Bahan & $76,15 \%$ & Sangat Valid \\
\hline 3 & Kebahasaan & $83,33 \%$ & Sangat Valid \\
\hline Jumlah Rata-rata & $\mathbf{8 1 , 3 8 \%}$ & Sangat Valid \\
\hline
\end{tabular}

Berdasarkan tabel diatas dapat disimpulkan bahwa dari 3 aspek penialain pada validasi materi yang dapat dideskripsikan sebagai berikut: 1) Kelayakan isi diperoleh skor 84, $67 \%$ dengan kategori sangat valid, 2) Penyajian bahan diperoleh skor $76,15 \%$ dengan kategori sangat valid, dan 3) Kebahasaan diperoleh skor $83,33 \%$ dengan kategori sangat valid. Sehingga diperoleh rata-rata keseluruhan yaitu $\mathbf{8 1 , 8 3} \%$ dengan kategori sangat valid. Sedangkan validasi media
Gorga Jurnal Seni Rupa

Volume 08 Nomor 01 Januari-Juni 2019

p-ISSN: 2301-5942 | e-ISSN: 2580-2380

dirangkum kategori validasi yang dinilai sebagaimana pada tabel berikut :

Tabel 2. Hasil Validitas dari Ahli Media

\begin{tabular}{|c|c|c|c|}
\hline No. & Aspek Penilaian & $\begin{array}{c}\text { Hasil } \\
\text { Validasi (\%) }\end{array}$ & Kategori \\
\hline 1 & Kegrafikan & $82,73 \%$ & Sangat Valid \\
\hline 2 & Isi & $76 \%$ & Sangat Valid \\
\hline 3 & Kebahasaan & $80 \%$ & Sangat Valid \\
\hline & & $\mathbf{7 9 , 5 7 \%}$ & Sangat Valid \\
\hline
\end{tabular}

Berdasarkan tabel diatas dapat disimpulkan bahwa dari 3 aspek penilaian pada validasi media dapat dideskripsikan sebagai berikut: 1) Kegrafikan diperoleh skor 82,73\% dengan kategori sangat valid, 2) Isi diperoleh skor $76 \%$ dengan kategori sangat valid, dan 3) Kebahasaan diperoleh $80 \%$ dengan kategori sangat valid. Sehingga diperoleh rata-rata keseluruhan yaitu $\mathbf{7 9 , 5 7 \%}$ dengan kategori Sangat Valid. Untuk lebih jelasnya dapat dilihat dalam lampiran

Sehingga hasil gabungan antara tabel 2 dan tabel 3 dapat dilihat validasi modul pembelajaran pembuatan kantong yaitu 80,7 \% dengan kategori Sangat Valid.

Hasil tersebut diperkuat dengan pendapat Riduwan (2012:22) bahwa skor tingkat pencapaian validitas suatu modul masuk dalam katergori sangat valid apabila berada pada skor $80-100 \%$. Sehingga modul pembelajaran Teknik Pembuatan Kantong pada Mata Kuliah Teknologi Busana valid atau layak digunakan.

\section{(2).Praktikalitas Modul Pembelajaran}

Tahap praktikalitas dilakukan dengan melakukan uji coba kepada dosen pembina mata kuliah dan mahasiswa untuk melihat kemudahan dalam penggunaan modul pembelajaran yang digunakan. Dan uji praktikalitas modul pembelajaran teknik pembuatan kantong diambil dari angket.

Setelah uji praktikalitas selesai, peneliti mengumpulkan angket praktikalitas yang sudah diisi untuk melakukan pengelompokkan skor yang diperoleh seperti tabel berikut: 
Tabel 3. Uji Praktikalitas Dosen Pembimbing Mata Kuliah

\begin{tabular}{|c|c|c|c|}
\hline No & $\begin{array}{c}\text { Aspek } \\
\text { Penilaian }\end{array}$ & $\begin{array}{c}\text { Hasil Praktikalitas } \\
(\mathbf{\%})\end{array}$ & Kategori \\
\hline 1 & $\begin{array}{c}\text { Kelayakan } \\
\text { Tampilan }\end{array}$ & $90 \%$ & Sangat praktis \\
\hline 2 & $\begin{array}{c}\text { Penyajian } \\
\text { Materi }\end{array}$ & $86 \%$ & Sangat praktis \\
\hline 3 & Manfaat & $95 \%$ & Sangat praktis \\
\hline & Rata-rata & $\mathbf{9 0 , 3 3 \%}$ & Sangat praktis \\
\hline
\end{tabular}

Berdasarkan dari tabel diatas dapat disimpulkan bahwa dari 3 aspek yang dinilai dapat diperoleh ratarata hasil praktikalitas dengan dosen pembina mata kuliah diperoleh skor 90,33 \% dengan kategori sangat praktis.

Hasil ketiga uji praktikalitas tersebut diperkuat dengan pendapat dari Riduwan (2010:98) bahwa skor presentase dengan tingkat pencapaian $90-100 \%$ dapat di kategorikan sangat praktis.

Hasil tersebut menunjukkan bahwa modul teknik pembuatan kantong pada mata kuliah teknologi busana sangat praktis untuk digunakan mahasiswa dalam belajar.

Selanjutnya dilakukan uji praktikalitas kelompok kecil dipilih 6 mahasiswa S1 Pendidikan Kesejahteraan Keluarga angkatan 2018 yang telah mengikuti perkuliahan Teknologi Busana. Pada uji praktikalitas ini dilakukan secara acak, kemudian angket praktikalitas diisi oleh mahasiswa. Hasilnya dapat dilihat pada tabel berikut:

Tabel 4. Uji Praktikalitas Kelompok Kecil

\begin{tabular}{|c|c|c|c|}
\hline No. & $\begin{array}{c}\text { Aspek } \\
\text { Penilaian }\end{array}$ & $\begin{array}{c}\text { Hasil Praktikalitas } \\
(\boldsymbol{\%})\end{array}$ & Kategori \\
\hline 1 & $\begin{array}{c}\text { Kelayakan } \\
\text { Tampilan }\end{array}$ & $86,67 \%$ & Sangat praktis \\
\hline 2 & $\begin{array}{c}\text { Penyajian } \\
\text { Materi }\end{array}$ & $90 \%$ & Sangat praktis \\
\hline 3 & Manfaat & $86,67 \%$ & Sangat praktis \\
\hline & Rata-rata & $\mathbf{8 7 , 7 7 \%}$ & Sangat praktis \\
\hline
\end{tabular}

Secara umum rata-rata hasil praktikalitas kelompok kecil diperoleh skor $87,77 \%$ dengan kategori sangat praktis, sehingga dapat dikatakan modul pembelajaran teknik pembuatan kantong sangat praktis untuk digunakan.

Selanjutnya dilakukan uji praktikalitas kelompok besar dengan melibatkan 30 orang mahasiwa S1 Pendidikan Kesejahteraan Keluarga angkatan 2018 yang telah mengikuti perkuliahan Teknologi Busana. Pada uji praktikalitas ini dilakukan secara acak,
Gorga Jurnal Seni Rupa

Volume 08 Nomor 01 Januari-Juni 2019

p-ISSN: 2301-5942 | e-ISSN: 2580-2380

kemudian angket praktikalitas diisi oleh mahasiswa. Hasilnya dapat dilihat pada tabel berikut:

Tabel 5. Uji Praktikalitas Kelompok Besar

\begin{tabular}{|c|l|c|c|}
\hline No. & $\begin{array}{c}\text { Aspek } \\
\text { Penilaian }\end{array}$ & $\begin{array}{c}\text { Hasil Praktikalitas } \\
(\boldsymbol{\%})\end{array}$ & Kategori \\
\hline 1 & $\begin{array}{l}\text { Kelayakan } \\
\text { Tampilan }\end{array}$ & $90 \%$ & Sangat Praktis \\
\hline 2 & $\begin{array}{l}\text { Penyajian } \\
\text { Materi }\end{array}$ & $82,73 \%$ & Praktis \\
\hline 3 & Manfaat & $84,71 \%$ & Sangat Praktis \\
\hline \multicolumn{2}{|c|}{ Rata-rata } & $\mathbf{8 5 , 8 1 \%}$ & Sangat Praktis \\
\hline
\end{tabular}

Secara umum rata-rata hasil praktikalitas kelompok kecil diperoleh skor $\mathbf{8 5 , 8 1 \%}$ dengan kategori Sangat Praktis , sehingga dapat dikatakan modul pembelajaran Teknik Pembuatan Kantong sangat praktis untuk digunakan.

\section{KESIMPULA DAN SARAN \\ 1.Kesimpulan}

Berdasarkan hasil penelitian yang telah dilakukan, diperoleh kesimpulan sebagai berikut:

Pengembangan modul pembelajaran Pembuatan Kantong dalam mata kuliah Teknologi Busana dilakukan dengan 3 tahap pengembangan yang tediri dari tahap pendefinisian (define), tahap perancangan (design) dan tahap pengembangan (develop). Validitas modul pembelajaran Pembuatan Kantong pada mata kuliah Teknologi Busana dari para ahli dinyatakan valid dengan skor $81,14 \%$ dengan skor $79,57 \%$ untuk ahli media dan 81, $38 \%$ untuk ahli materi. Praktikalitas modul pembelajaran Pembuatan kantong pada mata kuliah Teknologi Busana oleh dosen pembina mata kuliah dengan skor 90,33\% dan praktikalistas oleh mahasiswa dengan skor $85,81 \%$ dengan rata-rata $88,07 \%$. Maknanya modul pembelajaran dapat digunakan oleh mahasiswa sebagai bahan ajar.

\section{Saran}

Berdasarkan hasil penelitian yang telah penulis lakukan, maka penulis menyarankan agar hal-hal sebagai berikut:

Bagai mahasiswa diharapkan modul ini dimanfaatkan dalam pembelajaran Pembuatan Kantong pada mata kuliah Teknologi Busana. Bagi dosen diharapkan dapat membantu dalam menyampaikan materi Pembuatan Kantong pada mata kuliah Teknologi Busana. Bagi jurusan, dapat digunakan sebagai referensi untuk mahasiwa tentang pengembangan modul khususnya pada mata kuliah Teknologi Busana. Bagi penelitian selanjutnya yang sejenis dengan modul pembelajaran Pembuatan Kantong untuk dapat 


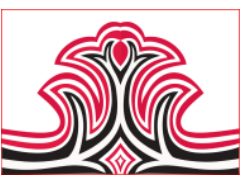

membuat modul yang lebih kreatif dan inovatif sehingga dapat menambah sumber belajar bagi mahasiswa. Karena keterbatasan yang penulis miliki, sebaiknya untuk di masa yang akan datang peneltian ini diselesaikan hingga tahap efektifitas.

\section{DAFTAR RUJUKAN}

Agus Purwanto, Erwan dan Dyah Ratih Sulistyastuti. (2007). Metode Penelitian Kuantitatif,Untuk Admnisitrasi Publik, dan Masalah-masalah Sosial. Jogyakarta: Gaya Media.

Arikunto, Suharsimi. (2009). Dasar-dasar Evaluasi Pendidikan. Jakarta: Bumi Aksara.

Goet poespo. (2005). Panduan Teknik Menjahit. Yogyakarta: Kanisius.

Muhibbin Syah. (2008). Psikologi Pendidikan dengan Pendekatan Baru. Bandung: Remaja Rosdakarya.

Riduwan. (2010). Belajar Mudah Penelitian Untuk Guru-Karyawan dan Peneliti Pemula. Bandung: Alfabeta.

Sugiyono. (2009). Metode Penelitian Pendidikan Pendekatan Kuantitatif, Kualitatif Dan $R \& D$. bandung: Alfabeta.

Trianto. (2009). Mendesain Model Pembelajaran Inovatif-Progresif. Jakarta: Kencana Perdana Group.

Vembriarto. (1981). Pengantar Pengajaran Modul. Yogyakarta: Paramita.

Wildari Zahri. (2007). Teknologi Menjahit Pakaian. Padang: UNP Press. 